\title{
ОЦІНКА ЯКОСТІ РОБОТИ МЕДИЧНИХ СЕСТЕР 3 ІНКУРАБЕЛЬНИМИ ХВОРИМИ В ГЕМАТОЛОГІЧНОМУ ВІДДІЛЕННІ КЗ ТОР «ТЕРНОПІЛЬСЬКА УНІВЕРСИТЕТСЬКА ЛІКАРНЯ»
}

\author{
Н. І. Рега, Б. А. Локай, С. О. Ястремська \\ КЗ ТОР «Тернопільська університетська лікарня» \\ ДВНЗ «Тернопільський державний медичний університет \\ імені І. Я. Горбачевського МОЗ Украйни»
}

\begin{abstract}
У статті викладено результати суб'єктивної оцінки якості роботи медичних сестер, які працюють з інкурабельними хворими в гематологічному відділенні К3 ТОР «Тернопільська університетська лікарня» за допомогою модифікованого опитувальника NEST, та запропоновано методи психологічної допомоги працівникам відділень паліативної терапії.
\end{abstract}

\section{QUALITY ASSESSMENT OF NURSING PERSONNEL'S WORK BY INCURABLE PATIENTS OF HEMATOLOGY DEPARTMENT ME OF TRC «TERNOPIL UNIVERSITY HOSPITAL»}

\author{
N. I. Rega, B. A. Lokay, S. O. Yastremska \\ ME of TRC «Ternopil University Hospital» \\ SHEI «Ternopil State Medical University by I. Ya. Horbachevsky of MPH of Ukraine»
}

The article describes the results of subjective evaluation by incurable patients of hematological department of ME of TRC «Ternopil University Hospital» using the modified NEST questionary and suggested methods of psychological help for the staff of palliative care departments.

Вступ. Паліативна допомога (ПД) - це підхід, який дозволяє покращити якість життя пацієнтів та членів їх сімей, що стикнулися з проблемою невиліковного захворювання, шляхом запобігання та полегшення страждань завдяки ранньому виявленню та точній оцінці проблем, що виникають, проведенню адекватних лікувальних втручань (при больовому синдромі та інших розладах життедіяльності) [5, 18], а також наданню психосоціальної та моральної підтримки $[6,7]$.

Головною метою ПД є підтримка якості життя у фінальній стадії, максимальне полегшення фізичних та моральних страждань пацієнта та його близьких, а також збереження людської гідності пацієнта. ПД можна надавати разом із допомогою, спрямованою на одужання, але іï мета не виліковування, а піклування [1]. Відповідно до сучасних міжнародних підходів та концепцій, паліативна медицина повинна бути невід'ємною, інтегрованою складовою медичного обслуговування та соціальної опіки. Декларація ВОО3 (1990р.) та Барселонська декларація (1996 р.) закликають усі держави світу включити ПД в структуру національних систем охорони здоров'я $[2,3,4]$.

Основна частина. Метою нашого дослідження було вивчення суб'єктивної оцінки якості роботи медичної сестри з інкурабельними пацієнтами гематологічного відділення КЗ ТОР «Тернопільська університетська лікарня».

(ㄱ Н. І. Рега, Б. А. Локай, С. О. Ястремська, 2015 
Відомо, що на термінальній стадії захворювання хворий та його родина зіштовхуються 3 низкою практичних проблем - потребою у спеціалізованій медичній допомозі, зміною звичного графіку роботи родичів або звільненням у зв'язку з необхідністю догляду за хворим, виникненням емоційних проблем і конфліктів у родині на фоні стресової ситуації, збільшення фінансових витрат. У зв'язку 3 погіршенням соматичного стану хворого, останній часто потребує спеціалізованої медичної допомоги, особливо такої, що стосуеться купірування вираженого больового синдрому, лікування легеневої недостатності, психотичних психічних розладів [8, 9]. Також зростає потреба у сторонній допомозі у зв'язку зі зменшенням здатності до самообслуговування. Важливим мотивом звернення до відділення паліативної допомоги $є$ наявність «соціальних показань» - надання родині хворого часу для відпочинку, вирішення нагальних питань або ж обмеження найбільш вразливих членів сім'ї (дітей, людей похилого віку) від споглядання страждань, пов'язаних із хворобою та вмиранням [10, 11].

Необхідно відмітити, що психіка хворого в термінальному періоді має свої особливості:

1) значне обмеження отримання зовнішньої інформації внаслідок обмеження руху, втрати професійної діяльності, звуження кількості особистісних контактів на фоні тяжкої ендогенної інтоксикації та больового синдрому звужують інтереси хворого, зміщують життєві цінності та сприяють заглибленню хворого у самого себе;

2) періоди активної психічної діяльності скорочуються, хворі швидко втомлюються, стають більш пасивними, наростає астенія, апатія;

3) у емоційному статусі часто домінуе відчуття безнадійності, пригніченість, зумовлені наявним комплексом симптомів хвороби, а також переживаннями стосовно прогнозу захворювання;

4) часто наявні страхи, особливо щодо обмеження функцій організму, втрати здатності до самообслуговування;

5) серйозним етапом стає розвиток хронічного больового синдрому та введення наркотичних знеболювальних засобів у комплекс лікувальних заходів;

6) на висоті больового синдрому може з'являтися схильність до реакцій гніву;

7) психічний стан хворих, як правило, корелюе з рівнем соматичного благополуччя, можливістю контролювати фізичні симптоми хвороби;

8) можуть бути присутні особистісні реакції на прогноз захворювання, що описуються терміном «переживання втрати», тобто це реакція на скорочення фізичних, соціальних можливостей, зміни у психічній сфері.

Вважається, що психологічні особливості хворого на термінальній стадії захворювання зумовлені такими чинниками:

1) швидкою зміною фізичного стану пацієнта 3 негативною тенденцією (постійне погіршення стану);

2) високим рівнем соматичного дистресу (больовий синдром, дихальна недостатність, нудота, кахексія, асцит та ін.);

3) обмеженими можливостями контролю за симптомами захворювання;

4) домінуванням у психічному стані негативних емоційних переживань (тривоги, страху, зниженого настрою, гніву та агресіі);

5) часто нереалістичними (завищеними) сподіваннями щодо можливостей власного організму перебороти хворобу або щодо можливостей медицини;

6) прогресивним виснаженням фізичного та психічного ресурсів хворого та людей із його близького оточення.

Психологічний стан осіб, які оточують невиліковно хворого в термінальній стадії вирізняеться послідовністю та етапністю особистісного реагування. Переживання виникають у відповідь на неспецифічні та специфічні симптоми захворювання, що свідчать про прогресування хвороби та несприятливий прогноз захворювання. Неспецифічними симптомами погіршення стану хворого є слабкість, швидка втомлюваність, погіршення апетиту, зниження активності та здатності до самообслуговування. Специфічні ознаки хвороби включають кровотечі, жовтяницю, асцит, ознаки пухлинного розпаду, патологічні переломи, виражений больовий синдром, розлади дихальної та травної систем та ін. Зокрема, потрібно відмітити, що звістка про неможливість проведення специфічної протипухлинної терапії та переведення хворого на паліативне лікування для оточуючих стає сильним психотравмуючим фактором $[13,17]$.

На фоні прогресування невиліковного захворювання та погіршення фізичного стану хворого, що виражається у відновленні симптомів хвороби та появі ускладнень, у поведінці оточуючих здебільшого спостерігається модель гіперопіки. Зазвичай хворого оберігають від правди про діагноз, орієнтують на позитивну перспективу щодо лікування та одужання. Мотивами такої поведінки є уявлення, що знання про тяжкість захворювання, і, відповідно, страх перед стражданнями та очікування неминучої смерті $\epsilon$ гіршими за саму смерть, також ви- 
словлюються побоювання щодо можливості вчинення паціентом суїциду. Тобто, така поведінка, на думку оточуючих, оберігає самого хворого. Однак з часом створюеться дисонанс між прогресуванням захворювання та відсутністю очікуваного ефекту від лікування. Тоді у відносинах із медичним персоналом у більшості випадків наростає напруження, виникають конфлікти. Усвідомлення того, що не потрібно чекати так званої легкої смерті пацієнта, постійні запитання хворого відносно перспектив лікування та одужання, що виникають на фоні прогресивного погіршення соматичного стану, зростання емоційних та фізичних потреб хворого приводять до бажання вийти з даної ситуації шляхом переходу до моделі дистанціювання. Внутрішне переживання відчуження та дистанціювання від хворого часто викликають у оточуючих почуття провини, яке, у свою чергу, стає вторинним психотравмуючим чинником. Та, незважаючи на виснаження емоційних та фізичних сил, як правило, на передній план виходить усвідомлення потреби здійснення догляду за тяжкохворим та почуття обов'язку. За умови успішного формування адаптації оточуючі вчаться долати власні переживання - відбувається повернення до «нейтральних» взаємин. Думки про власну смерть можуть також підштовхнути родичів хворих до визначення життєвих пріорітетів та краще пізнати себе, проживати залишок свого життя сповна, тоді стосунки між оточуючими та пацієнтом стають партнерськими [14].

Предметом дослідження стали специфіка роботи медичних сестер гематологічного відділення КЗ ТОР «Тернопільська університетська лікарня» та суб'ективна оцінка якості роботи медичних сестер 3 інкурабельними пацієнтами згідно 3 модифікованим опитувальником NEST.

Всього опитано 37 паціентів з гемобластозами в інкурабельній формі захворювання.

За результатами опитування оцінювали якість життя паціентів та якість надання паліативної медичної допомоги медичним персоналом відділення.

Оцінку якості надання паліативної медичної допомоги медичним персоналом відділення проводили за відповідями на такі запитання:

1. Як Ви вважаєте, наскільки добре Вас розуміють медичні сестри і ставляться до Вас 3 повагою?

2. Наскільки чіткою і зрозумілою е інформація, надана медичним персоналом, стосовно того, чого очікувати від Вашої хвороби?

3. Як Ви вважаєте, наскільки медичний догляд, що надається, відповідає Вашим цілям?
4. Як часто, на Вашу думку, Ви відчуваєте збентеженість, тривогу та пригніченість?

5. Наскільки складним для Вас виявився доступ до необхідного медичного догляду?

6. Наскільки Ви страждаєте від фізичних симптомів, включаючи біль, нестачу повітря, втому, проблеми зі шлунково-кишковим трактом та сечовипусканням?

7. Яка допомога Вам потрібна у сенсі піклування? Йдеться про забезпечення харчування.

8. Яка допомога Вам потрібна у сенсі піклування? Йдеться про забезпечення відвідування медичного персоналу.

9. Як часто поряд з Вами $є$ хтось, кому можна довіритися чи поділитися?

Оцінку якості життя інкурабельних хворих проводили за такими запитаннями:

1. Як часто, на Вашу думку, Ви відчуваєте збентеженість, тривогу та пригніченість?

2. Наскільки Ваша віра чи духовне життя сприяе Вашому відчуттю здоров'я і благополуччя?

3. Наскільки ця хвороба видається Вам безглуздою і непотрібною?

4. Чи є у Вас справи, які б Ви хотіли вирішити за допомогою Ваших близьких?

5. Після того, як Ви захворіли, чи залишилося у Вашому житті особливе відчуття цілі (мети)?

6. Наскільки фінансово обтяжливою $є$ Ваша хвороба для Вас та Вашої родини?

Відповіді оцінювали за 5-бальною системою:

1 бал - мало;

2 бали - посередньо;

3 бали - краще середнього;

4 бали - добре;

5 балів - дуже добре.

Результати опитування наведено в таблиці 1.

Із проаналізованих даних випливае, що якість надання пацієнтам паліативної допомоги медичними сестрами гематологічного відділення є досить високою (найбільша питома частка оцінок максимальні).

Більшість паціентів мали виражені соматичні та емоційні розлади (від помірних до максимально виражених).

Також майже всі паціенти відчували гостру потребу у відвідуванні медичного персоналу та у спілкуванні з особами, яким би вони могли довіритися і поділитися своїми проблемами.

Згідно з отриманими результатами, у більшості інкурабельних хворих значно знижувалася якість життя.

Враховуючи складну економічну ситуацію в Україні було проведено опитування, наскільки фінансово обтяжливою є хвороба для пацієнтів та їх родин. Отримані результати свідчили, що 


\begin{tabular}{|c|c|c|c|c|c|}
\hline \multirow[t]{2}{*}{ Запитання } & \multicolumn{5}{|c|}{$\begin{array}{c}\text { Кількість відповідей згідно з } \\
\text { оцінкою за 5-бальною шкалою }\end{array}$} \\
\hline & 1 & 2 & 3 & 4 & 5 \\
\hline $\begin{array}{l}\text { Як Ви вважаєте, наскільки добре Вас розуміють медичні сестри } \\
\text { і ставляться до Вас } 3 \text { повагою? }\end{array}$ & 3 & 2 & 1 & 1 & 30 \\
\hline $\begin{array}{l}\text { Наскільки чіткою і зрозумілою є інформація, надана медичним } \\
\text { персоналом, стосовно того, чого очікувати від Вашої хвороби? }\end{array}$ & 2 & 1 & 11 & 9 & 14 \\
\hline $\begin{array}{l}\text { Як Ви вважаєте, наскільки медичний догляд, що надається, відповідає } \\
\text { Вашим цілям? }\end{array}$ & 3 & 4 & 8 & 5 & 17 \\
\hline $\begin{array}{l}\text { Наскільки Ви страждаєте від фізичних симптомів, включаючи біль, } \\
\text { нестачу повітря, втому, проблеми зі шлунково-кишковим трактом та } \\
\text { сечовипусканням? }\end{array}$ & 4 & 3 & 18 & 8 & 4 \\
\hline $\begin{array}{l}\text { Як часто, на Вашу думку, Ви відчувасте збентеженість, тривогу та } \\
\text { пригніченість? }\end{array}$ & 4 & 5 & 13 & 6 & 10 \\
\hline $\begin{array}{l}\text { Наскільки Ваша віра чи духовне життя сприяє Вашому відчуттю здоров'я } \\
\text { і благополуччя? }\end{array}$ & 3 & 2 & 4 & 8 & 20 \\
\hline Наскільки ця хвороба видається Вам безглуздою і непотрібною? & 15 & 1 & 2 & 3 & 16 \\
\hline $\begin{array}{l}\text { Чи с у Вас справи, які б Ви хотіли вирішити за допомогою Ваших } \\
\text { близьких? }\end{array}$ & 7 & 6 & 4 & 8 & 12 \\
\hline $\begin{array}{l}\text { Після того, як Ви захворіли, чи залишиллося у Вашому житті особливе } \\
\text { відчуття цілі (мети)? }\end{array}$ & 1 & 3 & 7 & 12 & 14 \\
\hline $\begin{array}{l}\text { Наскільки складним для Вас виявився доступ до необхідного медичного } \\
\text { догляду? }\end{array}$ & 7 & 5 & 9 & 6 & 10 \\
\hline $\begin{array}{l}\text { Яка допомога Вам потрібна у сенсі піклування? Йдеться про забезпечення } \\
\text { харчування. }\end{array}$ & 7 & 3 & 8 & 7 & 12 \\
\hline $\begin{array}{l}\text { Яка допомога Вам потрібна у сенсі піклування? Йдеться про забезпечення } \\
\text { відвідування медичного персоналу. }\end{array}$ & 3 & 5 & 2 & 6 & 21 \\
\hline Як часто поряд з Вами с хтось, кому можна довіритися чи поділитися? & 1 & 2 & 8 & 5 & 21 \\
\hline $\begin{array}{l}\text { Наскільки фінансово обтяжливою є Ваша хвороба для Вас та Вашої } \\
\text { родини? }\end{array}$ & 6 & 5 & 1 & 4 & 21 \\
\hline
\end{tabular}

поганий фінансовий стан інкурабельних пацієнтів ще більше погіршував якість їх життя.

Висновки. 1.Якість надання паціентам паліативної допомоги медичними сестрами гематологічного відділення за оцінкою інкурабельних пацієнтів є досить високою (найбільша питома частка оцінок максимальні).

2. Більшість інкурабельних паціентів гематологічного відділення мають виражені соматичні та емоційні розлади (від помірних до максимально виражених). Багато осіб відчувае гостру потребу у відвідуванні медичного персоналу та у спілкуванні з людьми, яким би вони могли довіритися і поділитися своїми проблемами.

Поганий фінансовий стан інкурабельних пацієнтів за умов відсутності страхової медицини ще більше погіршуе якість їх життя.

Існують такі методи психологічної допомоги працівникам відділень паліативної допомоги $[15,16]$ :

1) психоосвіта;
2) тренінг комунікативних навичок;

3) тренінг поведінки в конфліктних ситуаціях;

4) психологічне консультування та психокорекція;

5) тематичні курси з психоонкології та паліативної медицини.

Тренінги для медичних працівників, як правило, орієнтовані на навчання:

- основ ефективного слухання;

- використання у бесідах відкритих запитань та узагальнень;

- покращення розпізнавання емоційних сигналів пацієнта;

- регулювання власного емоційного стану;

- підвищення емпатійності (розуміння пацієнта та співчуття до нього і співпереживання йому).

Отримані навички приводять, як правило, до формування достатнього терапевтичного альянсу з пацієнтом, і внаслідок залученості хворого до процесу лікування до покращення його психологічної адаптації [17]. 


\section{ЛITEPATУРА}

1. Князевич В. М. Паліативна і хоспісна медицина: концепція, складові, розвиток в Україні (за даними наукової літератури) / В. М. Князевич, З. М. Митник, Ю.І. Губський / / Україна - здоров'я нації. - 2009. № $3(11 / 09)$. - С. 55-63.

2. Новиков Г. А. Паллиативнаяпомощь онкологическим больным / Г. А. Новиков, В. И. Чиссов (ред.). М. : ООД: Медицина за качество жизни. - 2006. - 192 с.

3. Про утворення Інституту паліативної та хоспісної медицини МОЗ України : наказ МОЗ України № 159-0 від 24 липня 2008 p.

4. Government and NGOs cooperation to improve of palliative care specialists' education and training in Ukraine. / Tsarenko A., Gubskiy Yu. , Tchaykovska V., Stadnyuk L., Serdiuk V., Martynyuk-Gres' S. / $11^{\text {th }}$ Congress of the European Association for Palliative Care. 7 - 10.05.2009. Abstracts. - Austria. Vienna, 2009. - 149p.

5. Brennan F. Palliative Care as an International Human Right / F. Brennan // J. Pain Symptom Management. 2007. - Vol. 33 (5). - P. 494-499.

6. Callaway M. Advancing Palliative Care: The Public HealthPerspective. Foreword / M. Callaway, F.D. Ferris // J. Pain Symptom Management. - 2007.- Vol. 33 (5). P. 483-485.

7. Stjernsward J. The Public Health Strategy for Palliative Care / J. Stjernsward, K. M. Foley, F. D. Ferris / / J. Pain Symptom Management. - 2007. - Vol. 33(5). -P. 486-493.

8. Бондар Г. В. Паліативна медична допомога : посібник / Г. В. Бондар, І. С. Вітенко, О. Ю. Попович. Донецьк : Донеччина, 2004. - 80 c.

9. ICSI Assessment and Management of Chronic Pain, Fourth Edition, November 2009
10. Гнездилов А. В. Психология и психотерапия потерь / А. В. Гнездилов. - СПб. : Издательство «Речь», 2004. -162 c.

11. Гнездилов А. В. Психические изменения у онкологических больных / А. В. Гнездилов / / Практическая онкология. - 2001 . - № 1 (5). - С. 5-13.

12. Профілактикапрофесійного вигоранняпрацівників соціальної сфери : методичні рекомендації; за заг. ред. канд. мед. наук М. Л. Авраменка. - Всеукраїнський центр професійної реабілітації інвалідів. - Львів, 2008. -53 c.

13. Brandsen C. K. Social work and end-of-life palliative care: reviewing the past and moving forward / C. K. Brandsen / / Journal of Social Work in End-of-Life \& Palliative Care. - 2005. - Vol. 1. - P. 45-70.

14. ОрелВ. Е. Исследование феномена психического выгорания в отечественнойи зарубежнойпсихологии / В. Е. Орел // Проблемы общей и организационной психологии. - Ярославль, 1999. - С. 76-97.

15. ОсуховаН. Г. Сгоревшие наработе / Н. Г. Осухова , А. Е. Баринова / / Здоровье. - 2003. - № 9.

16. Стан паліативноїдопомогив Україні та медсестринська освіта / Р. І. Сидорчук, О. Й. Хомко, О. А. Рудек [таін.] / / Медична освіта. - 2008. - № 2. -С. 102-104.

17. Бачков И. В. Основы технологии группового тренинга. Психотехники : учебное пособие [текст] / И. В. Бачков. - М., 2000.

18. Improving of palliative care specialists' training in Ukraine / A.Tsarenko, V. Serdiuk, S. Martyniuk-Gres, L. Shkoba / / Palliative Care in Different Cultures. The 2nd International Conference in Palliative Care. - Eilat, Israel, 2008. $-80 p$. 